Historia Slavorum Occidentis

2020, nr 4 (27)

ISSN 2084-1213

DOI: $10.15804 /$ hso200410

JAKUB WOJTCZAK

ORCID: 0000-0002-0532-005X

\title{
Małgorzata Delimata-Proch, Rycheza, królowa Polski (ok. 995 - 21 marca 1063). Studium historiograficzne, Wydawnictwo Avalon, Kraków 2019, ss. 366
}

Małgorzata Delimata-Proch ukończyła studia doktorskie w 2002 r., broniąc pracę pt. Dziecko w Polsce średniowiecznej, napisaną pod kierunkiem prof. Jerzego Strzelczyka. W 2015 r. habilitowała się na podstawie pracy zatytułowanej Obce i rodzime władczynie polskiego średniowiecza w polskim piśmiennictwie XIX wieku. Ksztattowanie wizerunku i recepcja. Obydwie prace zostały opublikowane. Obecnie pełni funkcję profesora nadzwyczajnego na Wydziale Historii Uniwersytetu im. Adama Mickiewicza w Poznaniu.

Oprócz dwóch wspomnianych już monografii jest autorką wielu artykułów dotyczących historii medycyny, historii prawa miejskiego w Polsce czy przestępczości w Polsce w okresie nowożytnym. Do najważniejszych należą: Prawo rodzinne w pracach Barttomieja Groickiego (około 1534-1605) opublikowane w tomie Społeczeństwo staropolskie. Seria nowa, t. 3: Społeczeństwo a rodzina w 2011 r., Ciąza, poród i potóg w świetle polskich ksiag cudów i task (od średniowiecza do VIII w.) oraz Wypadki losowe oraz inne „wielkie niebieśpieczeństwa” w świetle księgi cudów i łask Matki Bożej Świętogórskiej (XVI-XVIII w.), które ukazały się w „Kwartalniku Historii Kultury Materialnej” odpowiednio w latach 2015 i 2017, a także „(...) Prześcieradtem z ottarza głaszcza jego twarz, aby było piękne”, czyli o zwyczajach, praktykach oraz uroczystościach okołochrzcielnych $w$ Polsce do XVI wieku opublikowany w monografii Miejsca chrztu, urządzenia baptyzmalne i ceremoniat chrzcielny od starożytności chrześcijańskiej 
do Soboru Trydenckiego pod redakcją prof. Andrzeja Marka Wyrwy w $2016 \mathrm{r}$.

W kręgu zainteresowań Małgorzaty Delimaty-Proch są również władczynie z okresu średniowiecza i właśnie jednej z nich jest poświęcona recenzowana tu publikacja. Nie jest to pierwszy raz, kiedy autorka stara się przybliżyć postać królowej Rychezy ${ }^{1}$, teraz jednak postanowiła przedstawić pierwszą próbę weryfikacji poglądów na jej temat. I choć wcześniej powstały artykuły i rozdziały w monografiach naukowych poświęcone córce palatyna reńskiego Ezzona² ${ }^{2}$ to do tej pory królowa Polski nie doczekała się swojej biografii.

Książka została podzielona na pięć rozdziałów, opowiadających o życiu i działalności Rychezy Lotaryńskiej zgodnie z jej chronologią życia. We wstępie (s. 9-16) autorka wskazuje na problem z napisaniem biografii postaci z epoki wczesnego średniowiecza, jak również przybliża wcześniejsze dzieła poświęcone tej władczyni. Rozdział I zatytułowany „Na łonie rodziny” (s. 17-55) rozpoczyna historia rodu, z którego pochodziła bohaterka książki, a więc lotaryńskich Ezzonidów. Następnie dowiadujemy się o genezie jej imienia i edukacji.

1 M. Delimata-Proch, Polscy historycy doby romantyzmu o królowej Polski Rychezie. W kręgu mitów historycznych, „Res Historica” 35 (2013), s. 11-30; taż, Królowa Rycheza w opinii kronikarzy i w polskiej historiografii, [w: ] Nihil superfluum esse. Studia z dziejów średniowiecza ofiarowane Profesor Jadwidze Krzyżaniakowej, red. J. Strzelczyk, J. Dobosz, Poznań 2000, s. 123-128; taż, Ucieczka z Polski i niemieckie losy królowej Rychezy (po 1031-1063), [w:] Decendo Discimus. Studia historyczne ofiarowane Profesorowi Zbigniewowi Wielgoszowi $w$ siedemdziesiąta rocznicę urodzin, red. K. Kaczmarek, J. Nikodem, Poznań 2000, s. 77-98; taż, Żona Popiela, Rycheza i Agnieszka jako przykłady złych małżonek władców. Uwagi w świetle polskich kronik doby średniowiecza, [w:] Cognitioni gestorum. Studia z dziejów średniowiecza dedykowane Profesorowi Jerzemu Strzelczykowi, red. D.A. Sikorski, A.M. Wyrwa, Poznań 2006, s. 251-262.

2 Postacią Rychezy zajmowali się nie tylko polscy historycy, ale również, jeśli nie częściej, historycy niemieccy, zob. m.in.: E. Hlawitschka, Königin Richeza von Polen - Enkelin Herzog Konrads vons Schwaben, nicht Kaiser Ottos II.?, [w:] Institutionen, Kultur und Gesellschaft im Mittelalter. Festschrift für Josef Fleckenstein ze seinem 65. Geburtstag, hrsg. v. L. Fenske, W. Rösener, T. Zotz, Simaringen 1984, s. 221-244; K. Jasiński, Rycheza, żona króla polskiego Mieszka II, „Herald. Historia, Genealogia, Heraldyka” 8 (1994) s. 11-18; J. Dobosz, Rycheza, [w:] Stownik władców polskich, red. tenże, Poznań 1997, s. 316-318; P. Schreiner, Richeza, Königin von Polen und die Gönnerin der Abtei Brauweiler. Beziehungen zwischen Deutschen und Polen vor 1000 Jahren, Pulheimer Beiträge zur Geschichte und Heimatkunde, 19. Sonderveröffentlichung, Pulheim 1998; M. Tomaszek, Klasztor i jego dobroczyńcy. Średniowieczna narracja o opactwie Brauweiler i rodzie królowej Rychezy, Kraków 2007; G. Pac, Czy królowa Rycheza używała pieczęci?, „Kwartalnik Historyczny” 122 (2015) 1, s. 91-101; tenże, Kobiety $w$ dynastii Piastów. Rola społeczna piastowskich żon i córek do połowy XII wieku - studium porównawcze, Toruń 2013. 
O wiele obszerniejszy jest rozdział II, noszący tytuł „Rycheza i Mieszko II” (s. 56-128). Tutaj Delimata-Proch rozprawia się z hipotezami dotyczącymi zaręczyn i zaślubin Rychezy z następcą tronu, synem Bolesława Chrobrego - Mieszkiem. Równocześnie zastanawia się nad okolicznościami połączenia siostrzenicy cesarza niemieckiego i księcia polskiego węzłem małżeńskim, poszukując inicjatorów tychże zaślubin. Następnie analizuje potomstwo Rychezy, genezy ich imion, daty narodzin itd. Autorka skupia się nie tylko na Kazimierzu, który przejął władzę po ojcu, ale równie dużo miejsca poświęca zarówno żonie Izasława I, wielkiego księcia kijowskiego Gertrudzie, jak i nieznanej z imienia małżonce króla Węgier Beli I. Nie zabrakło również wzmianki o rzekomym najstarszym synu Rychezy - Bolesławie „Zapomnianym", który w opinii współczesnych badaczy jest postacią bardziej legendarną niż historyczną. W dalszej części autorka koncentruje się na początkach bytności Rychezy w kraju swojego męża, jej koronacji, jak również działalności związanej z piśmiennictwem czy wspieraniem Kościoła w Polsce.

W rozdziale III „Burzliwe i tajemnicze lata trzydzieste XI wieku” (s. 129-200) autorka przybliża liczne hipotezy dotyczące życia i działalności królowej Rychezy po śmierci jej męża. Na wiele pytań z tego okresu nie da się odpowiedzieć, co autorka zaznacza. Historycy zaproponowali do tej pory niezmiernie dużo hipotez, jednakże brak źródeł nie daje konkretnej odpowiedzi na takie pytania, jak np.: kiedy i w jakich okolicznościach Rycheza wyjechała z Polski i czy zabrała ze sobą syna lub insygnia królewskie. Pojawia się także problem potencjalnych rządów opiekuńczych lub współudziału we władzy. Na końcu Delimata-Proch dokonuje podsumowania hipotez, wyrażając swoje zdanie na ich temat.

Rozdział IV zatytułowany „Na obcej/rodzimej ziemi” (s. 201-272) jest poświęcony życiu królowej Rychezy po opuszczeniu Polski i emigracji do Rzeszy. Autorka wskazuje na to, że w odróżnieniu od innych władców i władczyń zmuszonych do emigracji o działalności małżonki Mieszka II na obczyźnie zachowało się dużo informacji. Przyczyn takiego stanu rzeczy można doszukiwać się przede wszystkim w tym, że Rycheza powróciła w okolice dobrze jej znane z czasów dzieciństwa. Delimata-Proch na początku przypomina o działaniach Rychezy związanych z dążeniami do powrotu do władzy jej syna. Podkreśla, że do samego końca bohaterka książki używała tytułu „królowej”. Również życiu zakonnemu władczyni został poświęcony dość duży fragment. Wiele informacji zawiera kolejna część monografii dotycząca śmierci i pochówku Rychezy. Autorka przytacza zapiski z ówczesnych nekrologów, wspominając przy okazji o kulcie, jakim otoczona jest królowa na terenie Niemiec, mimo że do jej beatyfikacji czy kanonizacji nigdy nie doszło. 
Ostatni rozdział zatytułowany „»Zagorzała Niemka «, a może »pani zacna «? Czyli o narodzinach i kresie pewnego stereotypu w polskim piśmiennictwie" (s. 273-320) jest poświęcony odbiorze królowej przez historyków i budowaniu jej wizerunku. Delimata-Proch przytacza tutaj wszystkie fazy deformacji wizerunku królowej oraz kreowanie negatywnego stereotypu niemieckiej małżonki Mieszka II przez kronikarza Jana Długosza i jego następców. Ze względu na swoje pochodzenie Rycheza była przez długi czas odbierana jako postać negatywna w historii Polski, co z biegiem czasu zaczyna się zmieniać, a jej starania o przywrócenie pełni władzy w rękach Piastów powoli stają się doceniane. W tym rozdziale jest również ukazany wizerunek Rychezy w tradycji wielkopolskiej i śląskiej.

Monografię zamyka indeks osobowy (s. 355-366) poprzedzony rozbudowaną bibliografią (s. 329-355) podzieloną na źródła średniowieczne i literaturę.

Małgorzata Delimata-Proch w swojej książce przytoczyła niemalże wszystkie informacje pochodzące ze średniowiecznych kronik i innych źródeł dotyczących Rychezy. Poczynając od historii jej rodziny, narodzin, zaślubin z Mieszkiem II, przez działalność w Polsce, emigrację i aktywność w kraju rodzinnym, na śmierci, pochówku i kulcie kończąc. Dodatkowym atutem omawianej książki jest ostatni rozdzial, w którym autorka rozprawia się z negatywnym stereotypem, jaki przez długi czas w historiografii wiązał się z bohaterką powieści. Jak sama autorka wskazuje, „najlepszym wyrazem hołdu złożonego Rychezie byłoby całościowe, w osobnej monografii, omówienie jej losów i działalności”’ . Recenzowane dzieło, zgodnie z zamierzeniem autorki, jest wyczerpującym studium historiograficznym poświęconym niedocenionej polskiej królowej Rychezie, małżonce Mieszka II i przodkini władców europejskich.

Nadesłana: 31 VIII 2020

Zaakceptowana: 27 IX 2020

mgr Jakub Wojtczak

Uniwersytet im. Adama Mickiewicza w Poznaniu

Wydział Historii

ul. Uniwersytetu Poznańskiego 7

61-614 Poznań

e-mail:kub.wojtczak@gmail.com

3 M. Delimata-Proch, Rycheza, królowa Polski (ok. 995-21 marca 1063). Studium historiograficzne, Kraków 2019, s. 9. 